\title{
Comparative genomic hybridization and chromosomal instability in solid tumours
}

\author{
PH Rooney ${ }^{1}$, GI Murray ${ }^{2}$, DAJ Stevenson ${ }^{3}$, NE Haites ${ }^{13}$, J Cassidy ${ }^{1}$ and HL McLeod ${ }^{1}$ \\ Departments of ${ }^{1}$ Medicine and Therapeutics, ${ }^{2}$ Pathology and ${ }^{3}$ Medical Genetics, University of Aberdeen, Foresterhill, Aberdeen AB25 $2 Z \mathrm{D}$, UK
}

Keywords: comparative genomic hybridization; solid tumour genetics; chromosomal instability

The rational development of new diagnostic or prognostic tumour markers and the identification of novel cellular targets for anticancer chemotherapy relies on a more definitive understanding of tumour biology. Classical approaches using cellular pharmacology, and more recently molecular pharmacology, have led to the discovery of a number of growth factors and their receptors as well as other proteins which has resulted in novel therapies (e.g. inhibitors of epidermal growth factor receptor tyrosine kinase) and prognostic markers (e.g. oestrogen receptor levels in breast cancer) (Levitzki et al, 1995; Dowsett et al, 1997). Using classical metaphase cytogenetic techniques, many chromosomal aberrations have been identified in human cancer cell lines and primary culture of haematological malignancies. This chromosomal information has facilitated identification of a number of important genes associated with tumorigenesis (e.g. loss of chromosomal material on $13 \mathrm{q}$ led to identification of tumour suppressor gene RB1; Vogel, 1979). However, the use of metaphase cytogenetic analysis has been limited in solid tumours, mainly due to the difficulties in growing primary cultures in which to generate tumour metaphase chromosomes. However, this changed with the development of comparative genomic hybridization (CGH) and its ability to globally assess the genome of solid tumours for areas of loss and/or gain without the need for tissue culture (Kallioniemi et al, 1992; Forozan et al, 1997; Ried et al, 1997). CGH involves a competitive in situ hybridization of fluorescently labelled tumour DNA and healthy control DNA to normal metaphase chromosomes (Figure 1). Computer-assisted fluorescence microscopy is then used to assess the intensity of fluorochrome across each human chromosome. The differences in tumour and control fluorescence intensity along each chromosome on the reference metaphase spread are a reflection of the copy number changes of corresponding sequences in the tumour DNA. If chromosomes or chromosomal subregions are present in identical copy number within both the tumour and the normal DNA, an equal contribution from each fluorochrome is seen. However, a change in the fluorescent signal is seen if certain chromosomal subregions are gained or lost in the tumour DNA (Figure 1). The intensity of this signal is proportional to the amount of gain and loss seen for each region in the tumour DNA (Kallioniemi et al,

Received 17 July 1998

Revised 28 September 1998

Accepted 21 October 1998

Correspondence to: HL McLeod
1992; Forozan et al, 1997). Regions with a high level of heterochromatin and centromeric regions are not informative with $\mathrm{CGH}$. CGH data for the $\mathrm{p}$ regions of acrocentric chromosomes (e.g. 13p, 14p and 15p) must be interpreted with caution as repetitive sequences in these regions can affect the efficiency of competitive hybridization. With current technology, CGH has a theoretical limit of detection for gain and loss of genetic material of 5-10 Mb. However, gain of DNA in regions as small as $50 \mathrm{~kb}$ have been described in situations where high level amplification has occurred (Ried et al, 1997).

Initial studies with CGH were restricted to DNA prepared from fresh or snap-frozen tumour material. More recently, technical advances have allowed the extraction of DNA from formalinfixed paraffin-embedded sections through the use of degenerate oligonucleotide primed polymerase chain reaction (DOP-PCR) (Isola et al, 1994; Kuukasjarvi et al, 1997). The DOP-PCR technique allows genome-wide amplification of tumour DNA from nanogram quantities to the micrograms needed for $\mathrm{CGH}$, and has enabled retrospective analysis of genomic loss and gain to be performed using DNA from archival material.

Although CGH analysis has been performed in a wide variety of adult and paediatric tumours, these results have not been extensively interpreted in the context of the $\mathrm{CGH}$ findings from other tumour types. In this review, the results of $\mathrm{CGH}$ analysis in 27 tumour types are evaluated to identify regions of loss or gain which are common to all malignancies as well as those which are specific for a given tumour type or tumour subtype. In addition, the degree of overall genomic instability for specific tumour types has been assessed.

\section{REVIEW OF THE LITERATURE}

The Institute for Scientific Information (ISI) database from March 1992 to August 1998 identified 100 papers which described CGH findings in 2210 solid tumours of 27 cancer types (Appendix). This included common tumours (colon, breast, lung), genderspecific tumours (ovarian, cervix, testicular, prostate), paediatric tumours (neuroblastoma, rhabdomyosarcoma) and less common tumours (brain, renal, uveal melanoma). For each paper, the patterns of loss and gain in the $\mathrm{p}$ and $\mathrm{q}$ arms of each chromosome were recorded separately. Such an approach may not always be sufficient, as variation in subregions of the same chromosomal arm could be masked in some cases. However, a narrower definition for regions of gain and/or loss was not possible due to differences in the way CGH results have been presented in the 


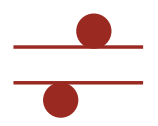

Normal DNA

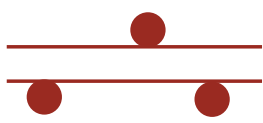

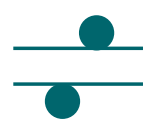

Tumour DNA

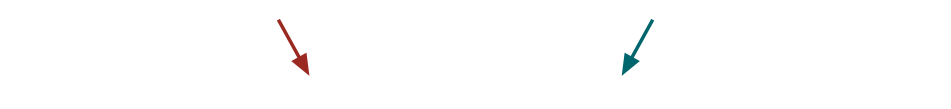

Hybridization

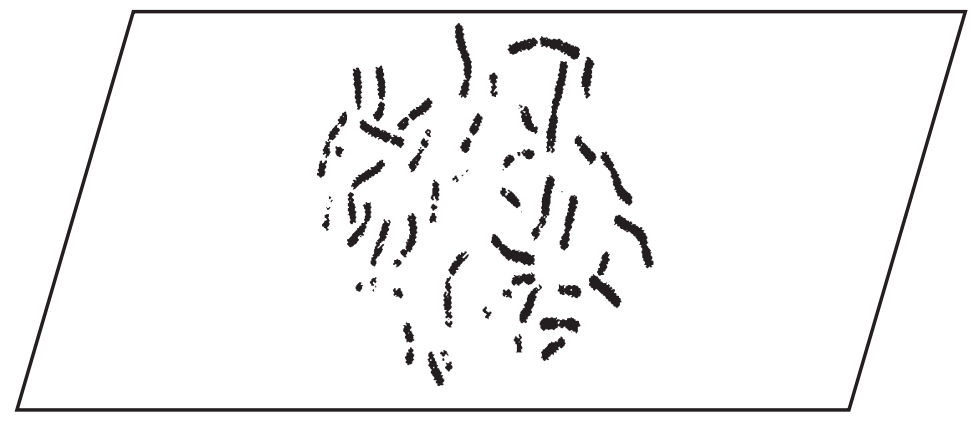

Normal human metaphase spread

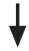

Fluorescence microscopy

$\downarrow$

Digital image analysis<smiles>[13CH3]</smiles>

Figure 1 A typical CGH experiment. Fluorescently labelled tumour DNA and reference DNA are competitively hybridized to donor human chromosomes. Using fluorescent microscopy the level of signal from the fluorescent DNA is assessed for each chromosome. For each chromosome a profile of the level of fluorescence is generated on CGH interpreting software. In most cases at least 10 chromosomes are assessed and an average of the fluorescence is generated. This allows regions of loss and gain that are consistently changed to be detected for a particular tumour sample

literature. Studies of CGH in patients with leukaemia, lymphoma or studies with incomplete details of results for individual chromosomes were not included in this review. Cell line data were not included due to the difficulty in differentiating between initial chromosomal aberrations and those 'acquired' during cell culture. The frequency of overall loss or gain for each chromosome arm was determined by pooling the data from all tumours, from a given tumour type and from specific tumour subtypes.

\section{PATTERNS OF CHROMOSOMAL LOSS AND GAIN}

\section{Solid tumours}

The frequency of loss or gain for each chromosome arm was determined for all the solid tumours by pooling the data found in the literature for 2210 tumours (Table 1). Gain of chromosomal material was found more frequently than loss among the solid 
Table 1 Loss and gain for each chromosomal arm when available CGH data from 2210 tumours (including 27 different solid tumour types) were pooled

\begin{tabular}{|c|c|c|c|c|c|}
\hline Chromosomal region & $\begin{array}{c}\text { Total tumour } \\
n=2210\end{array}$ & Gain (\%) & Chromosomal region & $\begin{array}{c}\text { Total tumour } \\
n=2210\end{array}$ & Loss (\%) \\
\hline $8 q+$ gains & 616 & 27.7 & $13 q-$ losses & 363 & 16.3 \\
\hline $1 q+$ gains & 558 & 25.1 & $9 p-$ losses & 357 & 16.1 \\
\hline $7 q+$ gains & 513 & 23.1 & $8 p-l o s s e s$ & 333 & 15 \\
\hline $7 p+$ gains & 477 & 21.5 & $10 q$-losses & 304 & 13.7 \\
\hline $17 q+$ gains & 412 & 18.5 & $3 p-$ losses & 297 & 13.4 \\
\hline $3 q+$ gains & 365 & 16.4 & $4 q-$ losses & 297 & 13.4 \\
\hline $20 q$ + gains & 344 & 15.5 & $6 q-$ losses & 296 & 13.3 \\
\hline $5 p+$ gains & 292 & 13.2 & $17 p-$ losses & 260 & 11.7 \\
\hline $12 q$ + gains & 290 & 13.1 & $18 q$-losses & 245 & 11 \\
\hline $12 p+$ gains & 277 & 12.5 & $1 p-$ losses & 226 & 10.2 \\
\hline $11 q+$ gains & 252 & 11.3 & $11 q-$ losses & 218 & 9.8 \\
\hline $6 p+$ gains & 246 & 11.1 & $5 q-$ losses & 206 & 9.1 \\
\hline $20 p+$ gains & 223 & 10 & $10 p-$ losses & 202 & 9.1 \\
\hline $19 q+$ gains & 223 & 10 & $16 q-$ losses & 196 & 8.8 \\
\hline $2 p+$ gains & 214 & 9.6 & $4 p-$ losses & 188 & 8.5 \\
\hline $13 q+$ gains & 205 & 9.2 & $22 q-$ losses & 184 & 8.3 \\
\hline $19 p+$ gains & 203 & 9.1 & $14 q$ - losses & 183 & 8.2 \\
\hline $1 p+$ gains & 201 & 9 & $9 q-$ losses & 170 & 7.7 \\
\hline $14 q+$ gains & 201 & 9 & $11 p-$ losses & 167 & 7.5 \\
\hline $2 q+$ gains & 198 & 8.9 & $15 q-$ losses & 161 & 7.2 \\
\hline $17 p+$ gains & 179 & 8.1 & $2 q-$ losses & 153 & 6.8 \\
\hline $16 p+$ gains & 176 & 7.9 & $X p-$ losses & 152 & 6.8 \\
\hline $8 p+$ gains & 175 & 7.9 & Xq-losses & 126 & 5.7 \\
\hline $15 q+$ gains & 174 & 7.8 & $21 q-$ losses & 122 & 5.5 \\
\hline $5 q+$ gains & 168 & 7.6 & $\mathrm{Y}-$ losses & 122 & 5.5 \\
\hline $6 q+$ gains & 164 & 7.4 & $18 p$ - losses & 119 & 5.4 \\
\hline $9 q+$ gains & 156 & 7 & $19 p-$ losses & 112 & 5 \\
\hline $18 p+$ gains & 153 & 6.9 & $17 q-$ losses & 105 & 4.7 \\
\hline $16 q+$ gains & 140 & 6.3 & $3 q-$ losses & 102 & 4.6 \\
\hline $18 q+$ gains & 136 & 6.1 & $12 q-$ losses & 98 & 4.4 \\
\hline $22 q+$ gains & 133 & 6 & $19 q$ - losses & 96 & 4.3 \\
\hline $10 p+$ gains & 131 & 5.9 & $1 q-$ losses & 89 & 4 \\
\hline$X q+$ gains & 129 & 5.8 & $6 p-$ losses & 84 & 3.8 \\
\hline $4 q+$ gains & 118 & 5.3 & $16 p-$ losses & 83 & 3.7 \\
\hline $10 q$ + gains & 117 & 5.3 & $5 p-$ losses & 83 & 3.7 \\
\hline $9 p+$ gains & 116 & 5.2 & $2 p-$ losses & 82 & 3.7 \\
\hline$X p+$ gains & 115 & 4.7 & $8 q-$ losses & 64 & 2.9 \\
\hline $3 p+$ gains & 104 & 4.7 & $7 q-$ losses & 56 & 2.5 \\
\hline $21 q+$ gains & 101 & 4.5 & $20 q-$ losses & 53 & 2.4 \\
\hline $11 p+$ gains & 97 & 4.4 & $20 p-$ losses & 53 & 2.4 \\
\hline $4 p+$ gains & 95 & 4.3 & $12 p$ - losses & 52 & 2.3 \\
\hline$Y+$ gains & 55 & 2.5 & $7 p-l o s s e s$ & 50 & 2.3 \\
\hline $14 p+$ gains & 24 & 1.1 & $22 p-$ losses & 36 & 1.6 \\
\hline $21 p+$ gains & 22 & 1 & $15 p-$ losses & 21 & 0.9 \\
\hline $13 p+$ gains & 17 & 0.8 & $14 p-$ losses & 10 & 0.5 \\
\hline $15 p+$ gains & 9 & 0.4 & $13 p-$ losses & 9 & 0.4 \\
\hline $22 p+$ gains & 6 & 0.3 & $21 p-$ losses & 3 & 0.1 \\
\hline Total gains & $9320 / 2210$ & 4.2 per tumour & Total losses & $6988 / 2210$ & 3.1 per tumour \\
\hline
\end{tabular}

tumours (mean 4.2 gain per tumour vs 3.1 loss per tumour). A variable pattern of chromosomal gain was observed, with the highest frequency of gain found in $8 \mathrm{q}(27.7 \%)$ and 1q $(25.1 \%)$ (Table 1$)$. This contrasts with chromosome $22 \mathrm{p}(0.3 \%)$ and $15 \mathrm{p}(0.4 \%)$ where gain of chromosomal material was rarely observed (Table 1). The most common regions of chromosomal loss were found on $13 q$ (16.3\% of all tumours), 9p (16.1\%) and $8 \mathrm{p}(15.0 \%)$ (Table 1$)$. Loss of chromosomal material was rarely seen on chromosome $21 \mathrm{p}(0.1 \%), 13 \mathrm{p}(0.4 \%)$ and $14 \mathrm{p}(0.5 \%)$. From Figure 2 it can be seen that levels of loss and gain are not uniform across all chromosomal regions. Certain chromosomal regions, such as $8 \mathrm{q}$, are often gained $(27.7 \%)$ but rarely lost $(2.9 \%)$. Similarly, loss in chromosome $4 \mathrm{q}$ was more common $(13.4 \%)$ than gain $(5.3 \%)$. This pattern was not seen for all chromosomes, with loss of $13 \mathrm{q}(16.3 \%)$ only 1.8 times more common than gain $(9.2 \%)$. Patterns of nearly equal frequency of loss and gain were also observed for chromosomes $14 \mathrm{q}$ ( $9 \%$ gain vs $8.2 \%$ loss) and $15 \mathrm{q}(7.8 \%$ gain vs $7.2 \%$ loss $)$. However, this does not take into account the specific region of a chromosomal arm to which the genetic loss or gene amplification in solid tumours is mapped. It also does not account for tumour-specific patterns of chromosomal gain and loss (Table 2), where the same chromosomal arm is rarely lost and gained to an equal extent for a particular tumour type. 


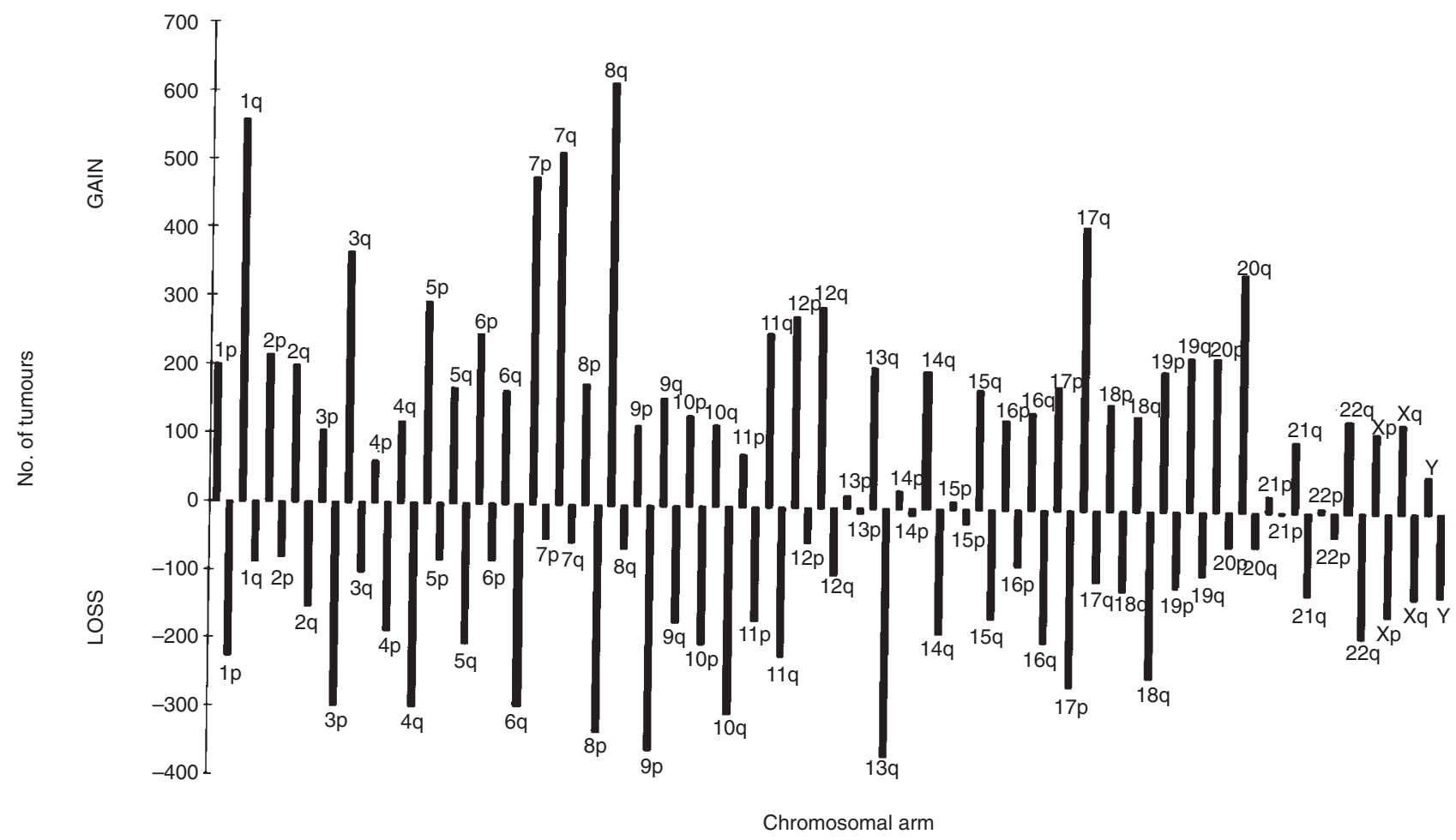

Figure 2 The overall number of gains and losses detected in 2210 solid tumours from 27 different tumour types

\section{Specific tumour types}

The frequency of chromosomal loss and gain varied between the individual tumour types, ranging from multiple regions per tumour (average gains: head and neck 12.2 per tumour, testicular 8.2 per tumour; loss: liver 7.5 per tumour, prostate 4.5 per tumour) to relatively rare events (average gains: neuroblastoma 0.5 per tumour, Wilms' 1.6 per tumour; loss: sarcoma 0.8 per tumour, Wilms' 1.3 per tumour (Table 3 ). The specific chromosomal regions of loss and gain differ substantially between specific tumour types. For example, gain in chromosome $12 \mathrm{p}$ occurred in $96.3 \%$ of testicular cancers and $0 \%$ of renal cancers (Table 2). New information on chromosomal loss or gain (Table 1) can be further specified amongst the various tumour types. For example, gain in chromosome $8 \mathrm{q}$ occurred in $27.7 \%$ of all tumours evaluated. However, on closer examination, frequency of $8 \mathrm{q}$ gain was high in tumours of the testis $(40.7 \%)$, ovary $(42.8 \%)$ and endometrium $(45.5 \%)$, but was rarely found in renal tumours $(1.3 \%)$ and neuroblastoma (3.0\%). There is no chromosomal arm which demonstrated a consistent pattern of gain for all tumour types. Similar findings were demonstrated for chromosomal loss. For instance, $9 \mathrm{p}$ was lost in $16.1 \%$ of all tumours, but varied from a high frequency event (cutaneous melanoma 58.2\%, pancreas $50.1 \%$, brain $36.3 \%$ ) to low (colon $7.5 \%$, gastric cancer $7 \%$ ) depending on the tumour type (Table 2).

\section{Specific tumour subtypes}

For several tumours, CGH analysis was available for multiple histological subtypes (Table 4). This allowed assessment of both the frequency at which loss and gain occurred and the extent to which each specific chromosomal arm is involved for each subtype.

\section{Colon}

Information on genomic alterations in colon cancer was available for low- and high-grade adenoma, primary carcinomas, liver metastases, and also carcinomas for which replication error repair status was known (Table 4). Ried et al (1995) found the frequency and degree of genetic aberrations increases with progression from low-grade adenoma through high-grade adenoma to carcinoma (Table 4). For example, gain in chromosome $7 \mathrm{p}$ was $7.1 \%$ in low-grade adenoma, $33.3 \%$ in high-grade adenoma and $50 \%$ in carcinoma. Similarly, gain in chromosome $20 \mathrm{q}$ was not detected in low-grade adenoma, but was at $33.3 \%$ and $75 \%$ in high-grade adenoma and carcinoma respectively. The frequency of alterations also increased with tumour progression: $3 / 47$ chromosomal arms in low-grade adenoma, 21/47 high-grade adenoma, 32/47 carcinomas. A separate study by Paredes-Zaglul et al (1998) comparing primary carcinomas and liver metastases from patients with colorectal cancer found that the frequency of alteration remained constant at $\sim 35 / 47$ chromosomal arms between these two stages. However, a change was noted in the extent to which these arms were involved. The most obvious change being the increase in loss of genetic material between primary tumour and liver metastases. For example, loss at $8 \mathrm{p}$ was $30 \%$ in primary carcinomas compared with $80 \%$ in metastases. Similarly, loss of $18 \mathrm{q}$ was found in $50 \%$ of primary cases, but $90 \%$ of liver metastases. Changes in gain did not always follow the same pattern seen for loss. An increase in genetic instability was seen for some chromosomal regions in the transition from primary to metastases (e.g. 13q was gained in $30 \%$ of primary tumours compared with $50 \%$ in metastases). However, this was not the case for other regions, such as $12 \mathrm{q}$, which was gained in $20 \%$ of primary carcinomas, but was normal in liver metastases. A difference in genetic instability was also seen between tumours with intact mismatch repair genes compared to 
Table 3 The number of altered chromosomal arms observed among the different tumour types

\begin{tabular}{|c|c|c|c|c|c|}
\hline Cancer type & Gains/tumour & & Losses/tumou & & $\begin{array}{c}\text { Total instability } \\
\text { (loss + gain) per tumour }\end{array}$ \\
\hline Gastric carcinoma & 365168 & 5.4 & $128 \backslash 68$ & 1.9 & 7.3 \\
\hline Gastrointestinal stromal & $52 \backslash 32$ & 1.6 & $71 \backslash 32$ & 2.2 & 3.8 \\
\hline Head and neck & $588 \backslash 47$ & 12.5 & $245 \backslash 47$ & 5.2 & 17.7 \\
\hline Pancreatic & $231 \backslash 51$ & 4.5 & $188 \backslash 51$ & 3.7 & 8.2 \\
\hline Colorectal & $204 \mid 80$ & 2.6 & $190 \backslash 80$ & 2.4 & 5 \\
\hline Prostate & $312 \backslash 100$ & 3.1 & $447 \backslash 100$ & 4.5 & 7.6 \\
\hline Testicular & $337 \backslash 41$ & 8.2 & $171 \backslash 41$ & 4.2 & 12.4 \\
\hline Breast & $752 \backslash 187$ & 4 & $549 \backslash 187$ & 2.9 & 6.9 \\
\hline Ovarian & $1136 \mid 203$ & 5.6 & $499 \backslash 203$ & 2.5 & 8.1 \\
\hline Endometrial & 186133 & 5.6 & 50133 & 1.5 & 7.1 \\
\hline Cervical & $163 \backslash 30$ & 5.4 & $124 \backslash 30$ & 4.1 & 9.5 \\
\hline Cutaneous melanoma & 203167 & 3 & $227 \backslash 67$ & 3.4 & 6.4 \\
\hline Merkel cell carcinoma & $23 \backslash 3$ & 8 & 1313 & 4.3 & 12.3 \\
\hline Uveal melanoma & $23 \backslash 11$ & 2.1 & $27 \backslash 11$ & 2.5 & 4.6 \\
\hline Renal & $346 \backslash 151$ & 2.3 & $530 \backslash 151$ & 3.5 & 5.8 \\
\hline Bladder & 222\96 & 2.3 & $278 \backslash 96$ & 2.9 & 5.2 \\
\hline Wilms' & $89 \backslash 54$ & 1.6 & $71 \backslash 54$ & 1.3 & 2.9 \\
\hline Connective tissue sarcoma & $530 \backslash 193$ & 2.7 & $154 \backslash 193$ & 0.8 & 3.5 \\
\hline Rhabdomyosarcoma & $158 \backslash 24$ & 6.6 & $61 \mid 24$ & 2.5 & 9.1 \\
\hline Lung & $845 \backslash 142$ & 6 & $599 \backslash 142$ & 4.2 & 10.2 \\
\hline Liver & $201 \backslash 43$ & 4.7 & $322 \backslash 43$ & 7.5 & 12.2 \\
\hline Neuroblastoma & $56 \backslash 118$ & 0.5 & $439 \backslash 118$ & 3.7 & 4.2 \\
\hline Brain & $1152 \backslash 325$ & 3.5 & $1076 \backslash 325$ & 3.3 & 6.8 \\
\hline Gastro-oesophageal & $100 \backslash 15$ & 6.7 & $50 \backslash 15$ & 3.3 & 10 \\
\hline Parathyroid & $38 \backslash 53$ & 7.2 & $121 \backslash 53$ & 2.3 & 9.5 \\
\hline Pituitary & $92 \backslash 23$ & 4 & 22153 & 4.2 & 8.2 \\
\hline Neuroendocrine* & $162 \backslash 20$ & 8.1 & $57 \backslash 20$ & 2.9 & 11 \\
\hline
\end{tabular}

*Sporadic neuroendocrine tumours of the digestive system.

those with deficient repair ability (Table 4). As expected, the tumours lacking repair function had a higher frequency of instability. For example, gain of $7 p$ and $7 q$ was seen in $33 \%$ of tumours with non-functioning repair genes, while these aberrations were absent in tumours with intact DNA repair phenotype. Although a relationship between genomic instability and both tumour progression and repair deficiency had been previously suggested, CGH has provided strong data to support this hypothesis in tumour specimens.

\section{Ovary}

Several studies have been published assessing the genomes of ovarian cancer cases. The available data were split into ovarian cancers derived from the epithelia and those derived from germ cells. Cancers of the epithelia were then further subdivided into sporadic and hereditary cases. The hereditary cases were defined as such based on BRCA1 and BRCA2 status. It is appreciated that some papers did not assess their cases for BRCA1 and BRCA2 and that a small percentage of the sporadic cases may have altered BRCA genes. Overall, however, this division of ovarian tumours has yielded some useful observations. Firstly, it was found that the frequency of genetic aberrations was greatest in the sporadic cases at $41 / 47$ chromosomal arms, compared with $33 / 47$ in hereditary cases and 30/47 in the germ cell tumours. The greatest level of concordance was at $1 \mathrm{q}$ and $8 \mathrm{q}$ where gains occurred at approximately $30 \%$ and $50 \%$, respectively, in all three tumour types. Both hereditary and sporadic cases had a high degree of gain at $3 \mathrm{q}$ (40.6\% in sporadic and 50\% in inherited cases). This is in contrast to the same region being gained in only $5.3 \%$ of germ cell tumours. However, all three tumour subtypes are likely to have some common genetic origin based on the observation that regions such as $1 \mathrm{q}$ and $8 \mathrm{q}$ are gained to an equal extent in all ovarian cancer types so far studied by $\mathrm{CGH}$.

\section{Prostate}

The data on prostate cancer allowed comparison of CGH results in patient cohorts with primary resected carcinomas or tumours that recurred after hormone therapy. It has been speculated that further genetic damage allows a subclone of tumour cells to acquire resistance to chemotherapy and such studies can test this hypothesis. Very little change in the frequency of genetic aberration between primary carcinoma and recurrent carcinoma was seen (39/47 in primary vs $42 / 47$ in recurrent). However, differences were seen in the degree of genetic aberration when specific chromosomal regions were considered. For example, gain in chromosome $8 \mathrm{q}$ was seen in $25.9 \%$ primary carcinomas compared with $73.9 \%$ in recurrent cases. Similarly, $19 \mathrm{p}$ was lost in $3.7 \%$ of primary tumours and $34.8 \%$ in recurrent cases. Gain in the region containing the androgen receptor gene, $\mathrm{Xp}$, increased from $7.4 \%$ in primary tumour to $28.3 \%$ in patients with recurrent disease. This is consistent with androgen receptor gene amplification as a mechanism of resistance to hormone therapy. However, this was not always the case with some regions of the genome only slightly changed in the degree of the aberration between primary and recurrent. For example, $3 p$ was lost in $1.9 \%$ of primary tumours and $4.3 \%$ in recurrent cases. Generally, the data support the hypothesis that increased tumour aggression is the phenotype of a more unstable genome. 
Table 4 Patterns of loss(-) and gain in specific tumour subtypes shown as the percentage of tumours with involvement for selected chromosomes

\begin{tabular}{|c|c|c|c|c|c|c|c|}
\hline $\begin{array}{l}\text { Tumour type } \\
\text { CR }\end{array}$ & $\begin{array}{c}\text { Colon† } \\
\text { Iga } \\
n=14\end{array}$ & $\begin{array}{l}\text { Hga } \\
n=12\end{array}$ & $\begin{array}{c}\text { Carcinoma } \\
n=16\end{array}$ & $\begin{array}{c}\text { Min- } \\
n=6\end{array}$ & $\begin{array}{l}\text { Min+ } \\
n=12\end{array}$ & $\begin{array}{c}\text { Primary } \\
n=10\end{array}$ & $\begin{array}{c}\text { Metastases } \\
\quad n=10\end{array}$ \\
\hline $7 p$ & 7.1 & 33.3 & 50 & 0 & 33.3 & 10 & 10 \\
\hline $7 q$ & 0 & 25 & 31.3 & 0 & 33.3 & 30 & 30 \\
\hline $8 p$ & 0 & 0 & 0 & 0 & 0 & $10 \&-30$ & $10 \&-80$ \\
\hline $12 q$ & 0 & 8.3 & 6.3 & 0 & 0 & 20 & 0 \\
\hline $13 q$ & 0 & 8.3 & 50 & -16.7 & 41.7 & $30 \&-10$ & 50 \\
\hline $18 q$ & 0 & -16.7 & -37.5 & 0 & -25 & -50 & -90 \\
\hline $20 q$ & 0 & 33.3 & 75 & 0 & 25 & 50 & 40 \\
\hline Involved arms & $3 \backslash 47$ & $21 \backslash 47$ & $32 \backslash 47$ & $3 \backslash 47$ & $22 \backslash 47$ & $34 \backslash 47$ & $35 \backslash 47$ \\
\hline Tumour type & $\begin{array}{c}\text { Ovary } \\
\text { Sporadic*}\end{array}$ & Inherited & OGCT & & & & \\
\hline CR & $n=148$ & $n=20$ & $n=19$ & & & & \\
\hline $1 q$ & $34.8 \&-0.7$ & 30 & 31.6 & & & & \\
\hline $2 q$ & $18.1 \&-1.4$ & $50 \&-5$ & 0 & & & & \\
\hline $3 q$ & 40.6 & 50 & $5.3 \&-5.3$ & & & & \\
\hline $8 q$ & $52.9 \&-0.7$ & 55 & 42.1 & & & & \\
\hline $21 q$ & $5.8 \&-7.2$ & 0 & 47.4 & & & & \\
\hline Involved arms & $41 \backslash 47$ & $33 \backslash 47$ & $30 \backslash 47$ & & & & \\
\hline Tumour type & $\begin{array}{l}\text { Prostate } \\
\text { Primary }\end{array}$ & Recurrent & & & & & \\
\hline CR & $n=54$ & $n=46$ & & & & & \\
\hline $3 p$ & -1.9 & $4.3 \&-4.3$ & & & & & \\
\hline $7 p$ & 3.7 & $34.8 \&-2.2$ & & & & & \\
\hline $7 q$ & $13 \&-1.9$ & $34.8 \&-2.2$ & & & & & \\
\hline $8 p$ & -46.5 & $8.7 \&-60.9$ & & & & & \\
\hline $8 q$ & 25.9 & 73.9 & & & & & \\
\hline $19 p$ & $7.4 \&-3.7$ & -34.8 & & & & & \\
\hline$X p$ & $7.4 \&-1.9$ & $28.3 \&-8.7$ & & & & & \\
\hline $\mathrm{Xq}$ & 14.8 & $15.2 \&-6.5$ & & & & & \\
\hline Involved arms & $39 \backslash 47$ & $42 \backslash 47$ & & & & & \\
\hline Tumour type & $\begin{array}{c}\text { Sarcoma } \\
\text { Osteosarcoma }\end{array}$ & RMS-E & RMS-A & Liposarcoma & ASPS & Ewing's & \\
\hline CR & $n=14$ & $n=10$ & $n=14$ & $n=14$ & $n=13$ & $n=20$ & \\
\hline $2 p$ & 0 & 50 & 50 & 0 & 0 & 5 & \\
\hline $6 \mathrm{p}$ & 28.6 & 0 & 7.1 & 0 & 0 & 10 & \\
\hline $2 q$ & 7.1 & 60 & -14.3 & 14.3 & 0 & 5 & \\
\hline $13 q$ & 14.3 & $60 \&-10$ & $35.7 \&-7.1$ & $7.1 \&-21.4$ & 0 & 5 & \\
\hline $16 q$ & 0 & $2 \&-30$ & $7.1 \&-7.1$ & 7.1 & -7.7 & $5 \&-5$ & \\
\hline Involved arms & $19 \backslash 47$ & $38 \backslash 47$ & $35 \backslash 47$ & $38 \backslash 47$ & $14 \backslash 47$ & $28 \backslash 47$ & \\
\hline
\end{tabular}

In several tumour subtypes both loss and gain were observed on the same chromosomal arm. Variation in the number of chromosomal arms involved in genetic instability was also observed between subtypes. *Contains tumours which were not evaluated for BRCA1 and BRCA2 status. † represents data from three separate studies evaluating tumour progression, microsatellite instability and metastasis respectively. $\mathrm{CR}=$ chromosomal region; Iga = low-grade adenoma; Hga = high-grade adenoma; OGCT = ovarian germ cell tumours; $\mathrm{MIN}+=$ without microsatellite instability; $\mathrm{MIN}-=$ with microsatellite instability; RMS-E = rhabdomyosarcoma embryonal; RMS-A = rhabdomyosarcoma alveolar; ASPS = alveolar soft part sarcoma

\section{Connective tissue tumours}

CGH data were available for several tumour types (liposarcoma, alveolar soft part sarcoma, osteosarcoma, Ewing's, rhabdomyosarcoma and osteochondroma). Unlike the other subtypes discussed (colon, ovary and prostate), tumours of the connective tissue are found in many different sites throughout the body. Considering the frequency of genetic aberration, the widest range of variation between subtypes among any tumour type in the literature is observed in the sarcomas. At one end of the spectrum a study on osteochondromas reports no genetic aberrations in 15 cases of this benign tumour type (Larramendy et al, 1997). Such a paper is unique in the $\mathrm{CGH}$ literature as all other investigations report some genomic change detectable by CGH. The alveolar soft part- and osteosarcomas show low to moderate frequency of genetic aberration at 14 and 19 out of 47 chromosomal arms respectively. While the other subtypes showed moderate to high numbers of arms involved (range 28-38 of 47). Another unique observation in the CGH literature was seen in an osteosarcoma study where only gain of genetic material was detected (Forus et al, 1995). Caution must be exercised when interpreting such results as it is unlikely that this cancer is the exception where no loss of genetic material is required for its development. More likely any loss, such as that of a tumour suppressor gene, is below detection by $\mathrm{CGH}$. Rhabdomyosarcomas are further subdivided histologically into alveolar and embryonal types. Generally, a higher degree of gain and loss is seen in the embryonal rhabdomyosarcoma compared 
with alveolar rhabdomyosarcoma (Weber-Hall et al, 1996). For example, a sub-chromosomal region of $13 q$ is gained in $60 \%$ and lost in $10 \%$ of embryoneal, while the same region is gained in $35.7 \%$ and lost in $7.1 \%$ of alveolar, rhabdomyosarcomas. The exception is $2 p$, which is lost in $50 \%$ of cases in both subtypes. Comparing both subtypes of rhabdomyosarcoma with other sarcomas it is observed that a gain of $2 q$ is not present in a high proportion in all sarcomas. In fact no change in $2 \mathrm{q}$ is detected in liposarcoma or alveolar soft part sarcoma and gain in Ewing's sarcoma is detected in less than $10 \%$ of all cases. This pattern of a certain chromosomal region commonly occurring in a specific subtype, but not in any other, continues for many chromosomal regions, suggesting that sarcomas are very distinct in terms of their genetic origin, with each subtype having its own marker chromosomal aberrations. This may be due to the variation in tissue type in which these tumours arise. No single chromosomal aberration was found to be present in a high proportion of all sarcomas.

\section{PATTERNS OF GENOMIC IMBALANCE OR INSTABILITY IN SOLID TUMOURS}

The degree of genomic imbalance detectable by CGH differs significantly between the various solid tumours (Table 3). Chromosomal gain varied from 0.5 to 12.5 chromosome arms per tumour with a median of 4.5 , while loss varied from 0.8 to 7.5 chromosomal arms per tumour with a median of 3.3. Total instability (chromosomal loss + chromosomal gain per number of tumours) was highest in head and neck tumours (17.7 lesions per tumour) and testicular (12.4 lesions per tumour) and lowest in Wilms' (2.9 lesions per tumour) and sarcoma (3.5 lesions per tumour) tumours. These frequencies represent an overall value for each specific tumour type, as information on the chromosomal alterations found within an individual tumour was not available in most literature reports of CGH in human solid tumours. Difference in the degree of loss or gain was also observed between the various solid tumours (Table 3). For example, chromosomal gain was observed more frequently than loss in the sarcomas and endometrial tumours, while loss was more frequently observed for renal and liver tumours. It is unknown whether these patterns represent coincidental changes from generalized genomic instability or suggest that some cancers are more likely to be influenced by the loss of tumour suppressor genes (genomic loss), while others are more frequently influenced by oncogene over expression (genomic gain). In addition, several studies have identified an association between the acquisition of genetic aberrations and patient survival (Iwabuchi et al, 1995; Tanner et al, 1995). However, there are discrepancies in this association found in Table 3, and any correlations between biological markers and patient survival need to be interpreted cautiously in the context of modern therapy.

\section{COMPARISON WITH SOLID TUMOUR KARYOTYPE ANALYSIS}

Classical karyotyping of metaphase chromosomes has been successfully performed for some solid tumours. A recent review reported the frequencies and distribution of chromosomal imbalances detected in 3185 solid tumours from 11 tumour types using chromosomal banding (Merkel et al, 1997). Overall, deletions were more common than gains in this analysis. Our review has found the opposite, with gains more commonly detected by CGH than losses.
This difference may reflect the difficulties with using tumour karyotyping to identify the chromosomal changes that have occurred in tumours with highly complex rearrangements and will be influenced to some extent by amplified segments being hidden among unidentified marker chromosomes. CGH should be more sensitive for the detection of the presence of gains than losses and therefore the discrepancies with the above study are likely to reflect technical limitations of the two methods. By restricting analysis to common alterations (i.e. the gain or loss was detected in at least $15 \%$ of the tumours studied for that particular tumour type), the classical karyotyping studies described fewer regions of gain and loss than $\mathrm{CGH}$ for every tumour type evaluated. CGH appeared to identify the same alterations described using the karyotyping approach (with the exception of balanced translocations which are not detectable by $\mathrm{CGH}$ ), but also observed additional regions of loss or gain. For example, only two regions of gain were detected in ovarian carcinoma by traditional cytogenetic analysis compared with 26 regions of gain seen by CGH. However, there have been too few studies of solid tumour cytogenetics using both $\mathrm{CGH}$ and chromosome banding for any firm conclusions regarding concordance between the two techniques. Nevertheless, the accumulating body of evidence in the literature suggests that $\mathrm{CGH}$ is more sensitive than other current technologies available for global assessment of loss and/or gain in solid tumour genomes.

\section{CONCLUSION}

From this review, it is apparent that no specific chromosomal imbalances are found in all cancers, with the most frequently identified regions of gain or loss occurring in $27.7 \%$ and $16.3 \%$ of tumours respectively. This reflects the heterogeneity in genomic alterations identified in different tumour types. In addition, much variation within tumour subtypes was observed.

The development of CGH has provided the technology to identify many new areas of genomic alteration which were not previously recognized to be altered in tumorigenesis. This has now expanded the number of areas of the genome for which more detailed molecular study is required to give a clearer more complete understanding of cancer biology.

Other areas where CGH could potentially make a significant contribution include its application in tumour diagnosis, as a prognostic tool, or for investigations into chemoresistance. The ability to assess the entire genome in a single experiment makes this technique potentially useful as an adjunct to routine histopathology. Several studies have established the feasibility of using CGH to detect genomic regions involved in the acquisition of resistance in human cancer cell lines and have detected novel regions of the genome not previously recognized to be involved in drug resistance (du Manoir et al, 1997; Wasenius et al, 1997; Leyland-Jones et al, 1998; Rooney et al, 1998). This provides the impetus to apply $\mathrm{CGH}$ to human tumour specimens in the context of modern drug therapy to assess its role in optimizing patient treatment.

\section{ACKNOWLEDGEMENTS}

Many thanks to Dr Lars-Peter Erwig for translation of a German paper. This work was supported in part by a University of Aberdeen Research Consortium studentship, a University of Aberdeen Equipment Award and an Aberdeen Royal Infirmary endowment grant. 


\section{REFERENCES}

Dowsett M, Daffada A, Chan CMW and Johnston SRD (1997) Oestrogen receptor mutants and variants in breast cancer. Eur J Cancer 33: 1177-1183

du Manoir S, Speicher MR, Joos S, Schrock E, Popp S, Döhner H, Kovacs G, Robert-Nicoud M, Lichter P and Cremer T (1993) Detection of complete and partial chromosome gains and losses by comparative genomic in situ hybridization. Hum Genet 90: 590-610

du Manoir S, Myers TG, Paull KD, Bell DW, Liu ZM, Feder MM, Weinstein JN, Sonoda G and Testa JR (1997) Analysis by CGH of the tumor cell lines of NCI anticancer drug discovery screen. Proc Am Assoc Cancer Res 38: 606

Forozan F, Karhu R, Kononen J, Kallioniemi A and Kallioniemi O-P (1997) Genome screening by comparative genomic hybridisation. TIGS 13: 405-409

Forus A, Olde Weghuis D, Smeets D, Fodstad Ø, Myklebost O and van Kessel AG (1995) Comparative genomic hybridization analysis of human sarcomas: II. Identification of novel amplicons at $6 \mathrm{p}$ and $17 \mathrm{p}$ in osteosarcomas. Genes Chromosomes Cancer 14: 15-21

Isola J, DeVries S, Chu L, Ghazvini S and Waldman F (1994) Analysis of changes in DNA sequence copy number by comparative genomic hybridization in archival paraffin-embedded tumor samples. Am J Pathol 145: 1301-1308

Iwabuchi H, Sakamoto M, Sakunaga H, Ma Y-Y, Carcangiu ML, Pinkel D, YangFeng TL and Gray JW (1995) Genetic analysis of benign, low-grade, and highgrade ovarian tumors. Cancer Res 55: 6172-6180

Kallioniemi A, Kallioniemi O-P, Sudar D, Rutovitz D, Gray JW, Waldman F and Pinkel D (1992) Comparative genomic hybridisation for the genetic analysis of solid tumours. Science 258: 818-821

Kallioniemi O-P, Kallioniemi A, Sudar D, Rutovitz D, Gray JW, Waldman F and Pinkel D (1993) Comparative genomic hybridization: a rapid new method for detecting and mapping DNA amplification in tumors. Semin Cancer Biol 4: $41-46$

Kuukasjarvi T, Tanner M, Pennanen S, Karhu R, Visakorpi T and Isola J (1997) Optimizing DOP-PCR for universal amplification of small DNA samples in comparative genomic hybridization. Genes Chromosomes Cancer 18: 94-101

Larramendy ML, Tarkkanen M, Blomqvist C, Virolainen M, Wiklund T, AskoSeljavaara S, Elomaa I and Knuutila S (1997) Comparative genomic hybridization of malignant fibrous histiocytoma reveals a novel prognostic marker. Am J Pathol 151: 1153-1161

Levitzki A and Gazit A (1995) Tyrosine kinase inhibition: an approach to drug development. Science 267: 1782

Leyland-Jones B, Bradshaw TD, Skelton L, Kelland LR, Fisher LM and Hiorns LR (1998) Genomic alterations associated with acquired resistance to novel antitumor agents. Proc Am Assoc Cancer Res 39: 658

Mertens F, Johansson B, Höglund M and Mitelman F (1997) Chromosomal imbalance maps of malignant solid tumors: a cytogenetic survey of 3185 neoplasms. Cancer Res 57: 2765-2780

Paredes-Zaglul A, Kang JJ, Essig YP, Mao WG, Irby R, Wloch M and Yeatman TJ (1998) Analysis of colorectal cancer by comparative genomic hybridization: evidence for induction of the metastatic phenotype by loss of tumor suppressor genes. Clin Cancer Res 4: 879-886

Ried T, Knutzen R, Steinbeck R, Blegen H, Schrock E, Heselmeyer K, duManoir S and Auer G (1996) Comparative genomic hybridization reveals a specific pattern of chromosomal gains and losses during the genesis of colorectal tumors. Genes Chromosomes Cancer 15: 234-245

Ried T, Liyanage M, du Manoir S, Heselmeyer K, Auer G, Macville M and Schröck E (1997) Tumor cytogenetics revisited: comparative genomic hybridisation and spectral karyotyping. J Mol Med 75: 801-814

Rooney PH, Marsh S, Stevenson DAJ, Johnston PG, Haites NE, Cassidy J and McLeod HL (1998) Genome wide assessment in cell lines resistant to thymidylate synthase inhibitors. Cancer Res 58: 5042-5045

Tanner MM, Tirkkonen M, Kallioniemi A, Holli K, Collins C, Kowbel D, Gray JW, Kallioniemi O-P and Isola J (1995) Amplification of chromosomal region $20 \mathrm{q} 13$ in invasive breast cancer: prognostic implications. Clin Cancer Res 1: $1455-1461$

Telenius H, Pelmear AH, Tunnacliffe A, Carter NP, Behmel A, Ferguson-Smith MA, Nordenskjold M, Pfragner R and Ponder BAJ (1992) Cytogenetic analysis by chromosome painting using DOP-PCR amplified flow-sorted chromosomes. Genes Chromosomes Cancer 4: 257-263

Vogel F (1979) Genetics of retinoblastoma. Hum Genet 52: 1-54

Waldman FM, Sauter G, Sudar D and Thompson CT (1996) Molecular cytometry of cancer. Hum Pathol 27: 441-449

Wasenius VM, Jekunen A, Monni O, Joensuu H, Aebi S, Howell SB and Knuutila S (1997) Comparative genomic hybridization analysis of chromosomal changes occurring during development of acquired resistance to cisplatin in human ovarian carcinoma cells. Genes Chromosomes Cancer 18: 286-291
Weber-Hall S, Anderson J, McManus A, Abe S, Nojima T, Pinkerton R, PritchardJones K and Shipley J (1996) Gains, losses, and amplification of genomic material in rhabdomyosarcoma analyzed by comparative genomic hybridization. Cancer Res 56: 3320-3224

\section{APPENDIX}

\section{Bladder}

Kallioniemi A, Kallioniemi O-P, Citro G, Sauter G, DeVries S, Kerschmann R, Caroll P and Waldman F (1995) Identification of gains and losses of DNA sequences in primary bladder cancer by comparative genomic hybridization. Genes Chromosomes Cancer 12: 213-219

Richter J, Jiang F, Görög J-P, Sartorius G, Egenter C, Gasser TC, Moch H, Mihatsch MJ and Sauter G (1997) Marked genetic differences between stage pTa and stage pT1 papillary bladder cancer detected by comparative genomic hybridization. Cancer Res 57: 2860-2864

Voorter C, Joos S, Bringuier P-P, Vallinga M, Poddighe P, Schalken J, du Manoir S, Ramaekers F, Lichter P and Hopman A (1995) Detection of chromosomal imbalances in transitional cell carcinoma of the bladder by comparative genomic hybridization. Am J Pathol 146: 1341-1354

\section{Brain}

Carlson KM, Bruder C, Nörderskjord M and Dumanski JP (1997) 1p and 3p deletions in meningiomas without detectable aberrations of chromosome 22 identified by comparative genomic hybridisation. Genes Chromosomes Cancer 20: $419-424$

Khan J, Parsa NZ, Harada T, Meltzer PS and Carter NP (1998) Detection of gains and losses in 18 meningiomas by comparative genomic hybridization. Cancer Genet Cytogenet 103: 95-100

Kim DH, Mohapatra G, Bollen A, Waldman FM and Feuerstein BG (1995) Chromosomal abnormalities in glioblastoma-multiforme tumors and glioma cell-lines detected by comparative genomic hybridization. Int J Cancer $\mathbf{6 0}$ : 812-819

Mohapatra G, Bollen AW, Kim DH, Lamborn K, Moore DH, Prados MD and Feuerstein BG (1998) Genetic analysis of glioblastoma multiforme provides evidence for subgroups within the grade. Genes Chromosomes Cancer 21 195-206

Nishizaki T, Ozaki S, Harada K, Ito H, Arai H, Beppu T and Sasaki K (1998) Investigation of genetic alterations associated with the grade of astrocytic tumor by comparative genomic hybridization. Genes Chromosomes Cancer $\mathbf{2 1}$ 340-346

Reardon DA, Michalkiewicz E, Boyett JM, Sublett JE, Entrekin RE, Ragsdale ST, Valentine MB, Behm FG, Li H, Heideman RL, Kun LE and Shapiro DN (1997) Extensive genomic abnormalities in childhood medulloblastoma by comparative genomic hybridization. Cancer Res 57: 4042-4047

Sallinen SL, Sallinen P, Haapasalo H, Kononen J, Karhu R, Helen P and Isola J (1997) Accumulation of genetic changes is associated with poor prognosis in grade II astrocytomas. Am J Pathol 151: 1799-1807

Schlegel J, Scherthan H, Arens N, Stumm G and Kiessling M (1996) Detection of complex genetic alterations in human glioblastoma multiforme using comparative genomic hybridization. J Neuropath Exp Neuro 55: 81-87

Schröck E, Thiel G, Lozanova T, du Manoir S, Meffert M-C, Jauch A, Speicher MR, Nürnberg P, Vogel S, Jänisch W, Doris-Keller H, Ried T, Witkowski R and Cremer T (1994) Comparative genomic hybridization of human malignan gliomas reveals multiple amplification sites and nonrandom chromosomal gains and losses. Am J Pathol 144: 1203-1218

Schröck E, Blume C, Meffert M-C, du Manior S, Bersch W, Kiessling M, Lozanowa T, Thiel G, Witkowski R, Ried T and Cremer T (1996) Recurrent gain of chromosome arm 7q in low-grade astrocytic tumors studied by comparative genomic hybridization. Genes Chromosomes Cancer $\mathbf{1 5}$ 199-205

Weber RG, Sommer C, Albert FK, Kiessling M and Cremer T (1996) Clinically distinct subgroups of glioblastoma multiforme studied by comparative genomic hybridisation. Lab Invest 74: 108-119

Weber RG, Sabel M, Reifenberger J, Sommer C, Oberstra $\beta$ J, Reifenberger G, Kiessling M and Cremer T (1996) Characterization of genomic alterations associated with glioma progression by comparative genomic hybridization. Oncogene 13: 983-994 


\section{Breast}

Courjal F and Theillet C (1997) comparative genomic hybridization analysis of breast tumors with predetermined profiles of DNA amplification. Cancer Res 57: 4368-4377

Guan X-Y, Xu J, Anzick SL, Shang H, Trent JM and Meltzer PS (1996) Hybrid selection of transcribed sequences from microdissected DNA: isolation of genes within an amplified region at 20q11-q13.2 in breast cancer. Cancer Res 56: $3446-3450$

Isola J, Kallioniemi O-P, Chu LW, Fuqua SAW, Hilsenbeck SG, Osborne K and Waldman FM (1995) Genetic aberrations detected by comparative genomic hybridization predict outcome in node-negative breast cancer. Am J Pathol 147 905-911

Kuukasjärvi T, Tanner M, Pennanen S, Karhu R, Kallioniemi OP and Isola J (1997) Genetic changes in intraductal breast cancer detected by comparative genomic hybridization. Am J Pathol 150: 1465-1471

Lu Y-J, Birdsall S, Osin P, Gusterson B and Shipley J (1997) Phyllodes tumors of the breast analyzed by comparative genomic hybridization and association of increased 1q copy number with stromal overgrowth and recurrence. Genes Chromosomes Cancer 20: 275-28

Nishizaki T, DeVries S, Chew K, Goodson WH III, Ljung B-M, Thor A and Waldman FM (1997) Genetic alterations in primary breast cancers and their metastases: direct comparison using modified comparative genomic hybridization. Genes Chromosomes Cancer 19: 267-272

Ried T, Just KE, Holtgreve-Grez H, du Manoir S, Speicher MR, Schröck E, Latham C, Blegen H, Zetterberg A, Cremer T and Auer G (1995) Comparative genomic hybridization of formalin-fixed, paraffin-embedded breast tumors reveals different patterns of chromosomal gains and losses in fibroadenomas and diploid and aneuploid carcinomas. Cancer Res 55: 5414-5423

Tanner MM, Tirkkonen M, Kallioniemi A, Collins C, Stokke T, Karhu R, Kowbel D, Shadravan F, Hintz M, Kuo W-L, Waldman FM, Isola J, Gray JW and Kallioniemi O-P (1994) Increased copy number at 20q13 in breast cancer: defining the critical region and exclusion of candidate genes. Cancer Res 54: 4257-4260

Tanner MM, Tirkkonen M, Kallioniemi A, Holli K, Collins C, Kowbel D, Gray JW, Kallioniemi O-P and Isola J (1995) Amplification of chromosomal region 20q13 in invasive breast cancer: prognostic implications. Clin Cancer Res $\mathbf{1}$ $1455-1461$

Tanner MM, Karhu RA, Nupponen NN, Borg A, Baldetorp B, Pejovic T, Ferno M, Killander D and Isola J (1998) Genetic aberrations in hypodiploid breast cancer: frequent loss of chromosome 4 and amplification of Cyclin D1 oncogene. Am J Pathol 153: 191-199

Tirkkonen M, Tanner M, Karhu R, Kallioniemi A, Isola J and Kallioniemi OP (1998) Molecular cytogenetics of primary breast cancer by CGH. Genes Chromosomes Cancer 21: 177-184

\section{Cervix}

Heselmeyer K, Macville M, Schröck Blegen H, Hellström A-C, Shah K, Auer G and Ried T (1997) Advanced-stage cervical carcinomas are defined by a recurrent pattern of chromosomal aberrations revealing high genetic instability and a consistent gain of chromosome arm 3q. Genes Chromosomes Cancer 19: 233-240

\section{Colon}

Nakao K, Shibusawa M, Tsunoda A, Yoshizawa H, Murakami M, Kusano M, Uesugi $\mathrm{N}$ and Sasaki K (1998) Genetic changes in primary colorectal cancer by comparative genomic hybridization. Surg Today-Jn J Surg 28: 567-569

Paredes-Zaglul A, Kang JJ, Essig YP, Mao WG, Irby R, Wloch M and Yeatman TJ (1998) Analysis of colorectal cancer by comparative genomic hybridization: evidence for induction of the metastatic phenotype by loss of tumor suppressor genes. Clin Cancer Res 4: 879-886

Ried T, Knutzen R, Steinbeck R, Blegen H, Schrock E, Heselmeyer K, duManoir S and Auer G (1996) Comparative genomic hybridization reveals a specific pattern of chromosomal gains and losses during the genesis of colorectal tumors. Genes Chromosomes Cancer 15: 234-245

Schlegel J, Stumm G, Scherthan H, Bocker T, Zirngibl H, Rüschoff J and Hofstädter F (1995) Comparative genomic in situ hybridization of colon carcinomas with replication error. Cancer Res 55: 6002-6005

\section{Cutaneous melanoma}

Bastian BC, Leboit PE, Hamm H, Brocker EB and Pinkel D (1998) Chromosomal gains and losses in primary cutaneous melanomas detected by comparative genomic hybridization. Cancer Res 58: 2170-2175
Wiltshire RN, Duray P, Bittner ML, Visakorpi T, Meltzer PS, Tuthill RJ, Liotta LA and Trent JM (1995) Direct visualization of the clonal progression of primary cutaneous melanoma: application of tissue microdissection and comparative genomic hybridization. Cancer Res 55: 3954-3957

\section{Endometrium}

Pere H, Tapper J, Wahlstrom T, Knuutila S and Butzow R (1998) Distinct chromosomal imbalances in uterine serous and endometrioid carcinomas. Cancer Res 58: 892-895

Sonoda G, du Manoir S, Godwin AK, Bell DW, Liu Z, Hogan M, Yakushiji M and Testa JR (1997) Detection of DNA gains and losses in primary endometrial carcinomas by comparative genomic hybridization. Genes Chromosomes Cancer 18: 115-125

\section{Gastroesophageal}

Moskaluk CA, Hu J and Perlman EJ (1998) Comparative genomic hybridization of esophageal and gastroesophageal adenocarcinomas shows consensus areas of DNA gain and loss. Genes Chromosomes Cancer 22: 305-311

\section{Gastrointestinal}

El-Rifai W, Sarlomo-Rikala M, Miettinen M, Knuutila S and Andersson LC (1996) DNA copy number losses in chromosome 14: an early change in gastrointestinal stromal tumors. Cancer Res 56: 3230-3233

\section{Gastric carcinoma}

Koizumi Y, Tanaka S-I, Mou R, Koganei H, Kokawa A, Kitamura R, Yamauchi H, Ookubo K, Saito T, Tominaga S, Matsumura K, Shimada H, Tsuchida N and Sekihara H (1997) Changes in DNA copy number in primary gastric carcinomas by comparative genomic hybridization. Clin Cancer Res $\mathbf{3}$ $1067-1076$

Kokkola A, Monni O, Puolakkainen P, Larramendy ML, Victorzon M, Nordling S, Haapiainen R, Kivilaakso E and Knuutila S (1997) 17q12-21 amplicon, a novel recurrent genetic change in intestinal type of gastric carcinoma: a comparative genomic hybridization study. Genes Chromosomes Cancer 20: 38-43

\section{Head and neck}

Speicher MR, Howe C, Crotty P, du Manoir S, Costa J and Ward DC (1995) Comparative genomic hybridization detects novel deletions and amplifications in head and neck squamous cell carcinomas. Cancer Res 55: $1010-1013$

Weber RG, Scheer M, Born IA, Joos S, Cobbers JL, Hofele C, Reifenberger G, Zoller JE and Lichter P (1998) Recurrent chromosomal imbalances detected in biopsy material from oral premalignant and malignant lesions by combined tissue microdissection, universal DNA amplification, and comparative genomic hybridization. Am J Pathol 153: 295-303

Wolff E, Girod S, Liehr T, Vorderwulbecke U, Ries J, Steininger H and Gebhart E (1998) Oral squamous cell carcinomas are characterized by a rather uniform pattern of genomic imbalances detected by comparative genomic hybridisation. Oral Oncol 34: 186-190

\section{Liver}

Marchio A, Meddeb M, Pineau P, Danglot G, Tiollais P, Bernheim A and Dejean A (1997) Recurrent chromosomal abnormalities in hepatocellular carcinom detected by comparative genomic hybridization. Genes Chromosomes Cancer 18: $59-65$

\section{Lung}

Balsara BR, Sonoda G, du Manoir S, Siegfried JM, Gabrielson E and Testa JR (1997) Comparative genomic hybridization analysis detects frequent, often high-level overrepresentation of DNA sequences at 3q, 5p, 7p and 8q in human non-small-cell lung carcinomas. Cancer Res 57: 2116-2120

Björkqvist A-M, Tammilehto L, Anttila S, Mattson K and Knuutila S (1997) Recurrent DNA copy number changes in 1q, 4q, 6q, 9p, 13q, 14q and 22q detected by comparative genomic hybridization in malignant mesothelioma. Br J Cancer 75: 523-527 
Björkqvist A-M, Tammilehto L, Nording S, Nurminen M, Anttila S, Mattson K and Knuutila S (1998a) Comparison of DNA copy number changes in malignant mesothelioma, adenocarcinoma and large-cell anaplastic carcinoma of the lung. Br J Cancer 77: 260-269

Björkqvist A-M, Husgafvel-Pursiainen K, Anttila S, Karjalainen A, Tammilehto L, Mattson K, Vainio H and Knuutila S (1998b) DNA gains in 3q occur frequently in squamous cell carcinoma of the lung, but not in adenocarcinoma. Genes Chromosomes Cancer 22: 79-82

Kivipensas P, Bjorkqvist A-M, Karhu R, Pelin K, Linnainmaa K, Tammilehto L, Mattson K, Kallioniemi O-P and Knuutila S (1996) Gains and losses of DNA sequences in malignant mesothelioma by comparative genomic hybridization. Cancer Genet Cytogenet 89: 7-13

Petersen I, Langreck H, Wolf G, Schwendel A, Psille P, Vogt P, Reichel MB, Ried T and Dietel M (1997a) Small-cell lung cancer is characterized by a high incidence of deletions on chromosomes 3p, 4p, 5q, 10q, 13q and 17p. $\mathrm{BrJ}$ Cancer 75: 79-86

Petersen I, Bujard M, Petersen S, Wolf G, Goeze A, Schwendel A, Langreck H, Gellert K, Reichel M, Just K, duManoir S, Cremer T, Dietel M and Ried T (1997b) Patterns of chromosomal imbalances in adenocarcinoma and squamous cell carcinoma of the lung. Cancer Res 57: 2331-2335

Ried T, Petersen I, Holtgreve-Grez H, Speicher MR, Schröck, du Manoir S and Cremer T (1994) Mapping of multiple DNA gains and losses in primary smallcell lung carcinomas by comparative genomic hybridization. Cancer Res $\mathbf{5 4}$ : $1801-1806$

\section{Merkel cell carcinoma}

Härle M, Arens N, Moll I, Back W, Schulz T and Scherthan H (1996) Comparative genomic hybridization (CGH) discloses chromosomal and subchromosomal copy number changes in Merkel cell carcinomas. J Cutan Pathol 23: 391-397

\section{Neuroblastoma}

Altura RA, Maris JM, Li H, Boyett JM, Brodeur GM and Look AT (1997) Novel regions of chromosomal loss in familial neuroblastoma by comparative genomic hybridization. Genes Chromosomes Cancer 19: 176-184

Brinkschmidt C, Christiansen H, Terpe HJ, Simon R, Lampert F, Bocker W and Storkel S (1996) Synopsis of unbalanced chromosomal-aberrations in neuroblastoma by comparative genomic hybridization. Pathologe 17: 368-373

Lastowska M, Cotterill S, Pearson AJ, Roberts P, McGuckin A, Lewis I and Bown N (1997) Gain of chromosome arm 17q predicts unfavourable outcome in neuroblastoma patients. Eur J Cancer 33: 1627-1633

Lastowska M, Nacheva E, McGuckin A, Curtis A, Grace C, Pearson A and Brown N (1997) Comparative genomic hybridization study of primary neuroblastoma tumors. Genes Chromosomes Cancer 18: 162-169

Plantaz D, Mohapatra G, Matthay KK, Pellarin M, Seeger RC and Feuerstein BG (1997) Gain of chromosome 17 is the most frequent abnormality detected in neuroblastoma by comparative genomic hybridization. Am J Pathol 150: 81-89

Schütz BR, Scheurlen W, Krauss J, du Manoir S, Joos S, Bentz M and Lichter P (1996) Mapping of chromosomal gains and losses in primitive neuroectodermal tumors by comparative genomic hybridization. Genes Chromosomes Cancer 16: $196-203$

Szymas J, Wolf G, Kowalczyk D, Nowak S and Petersen I (1997) Olfactory neuroblastoma: detection of genomic imbalances by comparative genomic hybridization. Acta Neurochir 139: 839-844

Van Gele M, Van Roy N, Jauch A, Laureys G, Benoit Y, Schelfhout V, De Porter CR, Brock P, Uyttebroeck A, Sciot R, Schuuring E, Versteeg R and Speleman F (1997) Sensitive and reliable detection of genomic imbalances in human neuroblastoma using comparative genomic hybridisation analysis. Eur $J$ Cancer 33: 1979-1982

\section{Neuroendocrine tumours of the digestive system}

Terris B, Meddeb M, Marchio A, Danglot G, Flejou JF, Belghiti J, Ruszniewski P and Bernheim A (1998) Comparative genomic hybridization analysis of sporadic neuroendocrine tumors of the digestive system. Genes Chromosomes Cancer 22: 50-56

\section{Ovary}

Arnold N, Hägele L, Walz L, Schempp W, Pfisterer J, Bauknecht T and Kiechle M (1996) Over-represenation of $3 q$ and $8 \mathrm{q}$ material and loss of $18 \mathrm{q}$ material are recurrent findings in advanced human ovarian cancer. Genes Chromosomes Cancer 16: 46-54

Iwabuchi H, Sakamoto M, Sakunaga H, Ma Y-Y, Carcangiu ML, Pinkel D, YangFeng TL and Gray JW (1995) Genetic analysis of benign, low-grade, and highgrade ovarian tumors. Cancer Res 55: 6172-6180

Riopel MA, Spellerberg A, Griffin CA and Perlman EJ (1998) Genetic analysis of ovarian germ cell tumors by comparative genomic hybridization. Cancer Res 58: $3105-3110$

Tapper J, Sarantaus L, Vahteristo P, Nevanlinna H, Hemmer S, Seppala M, Knuutila S and Butzow R (1998) Genetic changes in inherited and sporadic ovarian carcinomas by comparative genomic hybridization: extensive similarity except for a difference at chromosome 2q24-q32. Cancer Res 58: 2715-2719

Sonoda G, Palazzo J, du Manoir S, Godwin AK, Feder M, Yahushiji M and Testa JR (1997) Comparative genomic hybridisation detects frequent overrepresentation of chromosomal material from 3q26, 8q24 and 20q13 in human ovarian carcinomas. Genes Chromosomes Cancer 20: 320-328

Tapper J, Bützow R, Wahlstöm T, Seppälä M and Knuutila S (1997) Evidence for divergence of DNA copy number changes in serous, mucinous and endometrioid ovarian carcinomas. Br J Cancer 75: 1782-1787

\section{Pancreas}

Fukushige S, Waldman FM, Kimura M, Abe T, Furukawa T, Sunamura M, Kobari M and Horii A (1997) Frequent gain of copy number on the long arm of chromosome 20 in human pancreatic adenocarcinoma. Genes Chromosomes Cancer 19: 161-169

Mahlamäki EH, Höglund M, Gorunova L, Karhu R, Dawiskiba S, Andrén-Sandberg $\AA$, Kallionemi OP and Johansson B (1997) Comparative genomic hybridisation reveals frequent gains of $20 \mathrm{q}, 8 \mathrm{q}, 11 \mathrm{q}, 12 \mathrm{p}$ and $17 \mathrm{q}$, and losses of 18q, 9p and $15 q$ in pancreatic cancer. Genes Chromosomes Cancer 20: 383-391

Solinas-Toldo S, Wallrapp C, Müller-Pillasch F, Bentz M, Gress T and Lichter P (1996) Mapping of chromosomal imbalances in pancreatic carcinoma by comparative genomic hybridization. Cancer Res 56: 3803-3807

\section{Parathyroid}

Palanisamy N, Imanishi Y, Rao PH, Tahara H, Chaganti RK and Arnold A (1998) Novel chromosomal abnormalities identified by comparative genomic hybridization in parathyroid adenomas. J Clin Endocr Metab 83: 1766-1770

\section{Pituitary}

Daniely M, Aviram A, Adams EF, Buchfelder M, Barkai G, Fahlbusch R, Goldman B and Friedman E (1998) Comparative genomic hybridization analysis of nonfunctioning pituitary tumors. J Clin Endocr Metab 83: 1801-1805

\section{Prostate}

Cher ML, MacGrogan D, Bookstein R, Brown JA, Jenkins RB and Jensen RH (1994) Comparative genomic hybridization, allelic imbalance, and fluorescence in situ hybridization on chromosome 8 in prostate cancer. Genes Chromosomes Cancer 11: 153-162

Nupponen NN, Kakkola L, Koivisto P and Visakorpi T (1998) Genetic alterations in hormone-refractory recurrent prostate carcinomas. Am J Pathol 153: 141-148

Joos S, Bergerheim USR, Pan Y, Matsuyama H, Bentz M, du Manoir S and Lichter $\mathrm{P}$ (1995) Mapping of chromosomal gains and losses in prostate cancer by comparative genomic hybridization. Genes Chromosones Cancer 14: 267-276

Visakorpi T, Kallioniemi AH, Syvänen A-C, Hyytinen ER, Karhy R, Tammela T, Isola J and Kallioniemi O-P (1995) Genetic changes in primary and recurrent prostate cancer by comparative genomic hybridization. Cancer Res $\mathbf{5 5}$ : $342-347$

\section{Renal}

Bentz M, Bergerheim UR, Li C, Joos S, Werner CA, Baudis M, Gnarra J, Merino MJ, Zbar B, Linehan WM and Lichter P (1996) Chromosome imbalances in papillary renal cell carcinoma and first cytogenetic data of familial cases analyzed by comparative genomic hybridization. Cyto Cell Genet 75: 17-21

Gronwald J, Storkel S, Holtgreve Grez H, Hadaczek P, Brinkschmidt C, Jauch A Lubinski J and Cremer T (1997) Comparison of DNA gains and losses in primary renal clear cell carcinomas and metastatic sites: importance of $1 \mathrm{q}$ and 3p copy number changes in metastatic events. Cancer Res 57: 481-487 
Moch H, Presti JC, Sauter G, Buchholz N, Jordan P, Mihatsch MJ and Waldman FM (1996) Genetic aberrations detected by comparative genomic hybridization are associated with clinical outcome in renal cell carcinoma. Cancer Res 56: 27-30

Presti JC, Moch H, Reuter VE, Huynh D and Waldman FM (1996) Comparative genomic hybridization for genetic analysis of renal oncocytomas. Genes Chromosomes Cancer 17: 199-204

Presti JC, Moch H, Reuter VE, Cordoncardo C and Waldman FM (1996) Renal-cell carcinoma genetic-analysis by comparative genomic hybridization and restriction fragment length polymorphism analysis. J Urol 156: 281-285

\section{Rhabdomyosarcoma}

Weber-Hall S, Anderson J, McManus A, Abe S, Nojima T, Pinkerton R, PritchardJones K and Shipley J (1996) Gains, losses, and amplification of genomic material in rhabdomyosarcoma analyzed by comparative genomic hybridization. Cancer Res 56: 3320-3224

\section{Sarcoma}

Armengol G, Tarkkanen M, Virolainen M, Forus A, Valle J, Bohling T, AskoSeljavaara S, Blomqvist C, Elomaa I, Karaharju E, Kivioja AH, Siimes MA, Tukiainen E, Caballin MR, Myklebost O and Knuutila S (1997) Recurrent gains of 1q, 8 and 12 in the Ewing family of tumours by comparative genomic hybridization. Br J Cancer 75: 1403-1409

Forus A, Olde Weghuis D, Smeets D, Fodstad Ø, Myklebost O and van Kessel A-G (1995) Comparative genomic hybridization analysis of human sarcomas: 1. Occurrence of genomic imbalances and identification of a novel major amplicon at 1q21-q22 in soft tissue sarcomas. Genes Chromosomes Cancer 14 $8-14$

Forus A, Olde Weghuis D, Smeets D, Fodstad Ø, Myklebost O and van Kessel AG (1995) Comparative genomic hybridization analysis of human sarcomas: II. Identification of novel amplicons at $6 \mathrm{p}$ and $17 \mathrm{p}$ in osteosarcomas. Genes Chromosomes Cancer 14: 15-21

KiuruKuhlefelt S, ElRifai W, SarlomoRikala M, Knuutila S and Miettinen M (1998) DNA copy number changes in alveolar soft part sarcoma: a comparative genomic hybridization study. Mod Path 11: 227-231

Larramendy ML, Tarkkanen M, Blomqvist C, Virolainen M, Wiklund T, AskoSelijavaara S, Elomaa I and Knuutila S (1997a) Comparative genomic hybridization of malignant fibrous histiocytoma reveals a novel prognostic marker. Am J Pathol 151: 1153-1161

Larramendy ML, Valle J, Tarkkanen M, Kivioja AH, Karaharju E, Salmivalli T, Elomma I and Knuutila S (1997b) No DNA copy number changes in osteochondromas: a comparative genomic hybridization study. Cancer Genet Cytogenet 97: 76-78

Packenham JP, duManoir S, Schrock E, Risinger JI, Dixon D, Denz DN, Evans JC, Berchuck A, Barrett JC, Devereux TR and Ried T (1997) Analysis of genetic alterations in uterine leiomyomas and leiomyosarcomas by comparative genomic hybridization. Mol Carcinogen 19: 273-279

Szymanska J, Tarkkanen M, Wiklund T, Virolainen M, Blomqvist C, AskoSeljavaara S, Tukiainen E, Elomaa I and Knuutila S (1996) Gains and losses of DNA sequences in liposarcomas evaluated by comparative genomic hybridization. Genes Chromosomes Cancer 15: 89-94
Szymanska J, Mandahl N, Mertens F, Tarkkanen M, Karaharju E and Knuutila S (1996) Ring chromosomes in parosteal osteosarcoma contain sequences from 12q13-15: a combined cytogenetic and comparative genomic hybridization study. Genes Chromosomes Cancer 16: 31-34

\section{Testicular}

Decker H-JH, Neuhaus C, Jauch A, Speicher M, Ried T, Bujard M, Brauch H, Störkel S, Stöckle M, Selger B and Huber C (1996) Detection of a germline mutation and somatic homozygous loss of the von Hippel-Lindau tumorsuppressor gene in a family with a de novo mutation. A combined genetic study, including cytogenetics, PCR/SSCP, FISH, and CGH. Hum Genet 97: 770-776

Korn WM, Olde Weghuis DEM, Suijkerbuijk RF, Schmidt U, Otto T, du Manoir S, van Kessel AG, Harstrick A, Seeber S and Bechre R (1996) Detection of chromosomal DNA gains and losses in testicular germ cell tumours by comparative genomic hybridization. Genes Chromosomes Cancer 17: 78-87

Mostert MMC, van de Pol M, Olde Weighuis D, Suijkerbuijk RF, van Kessel AG, van Echten J, Oosterhuis JW and Looijenga LHJ (1996) Comparative genomic hybridization of germ cell tumors of the adult testis: confirmation of karyotypic findings and identification of a 12p-amplicon. Cancer Genet Cytogenet $\mathbf{8 9}$ : $146-152$

Ottesen AM, Kirchhoff M, Rajpert EW, Maahr J, Gerdes T, Rose H, Lundsteen C, Petersen PM, Philip J and Skakkebaek NE (1997) Detection of chromosomal aberrations in seminomatous germ cell tumours using comparative genomic hybridisation. Genes Chromosomes Cancer 20: 412-418

Speicher MR, Jauch A, Walt H, du Manoir S, Ried T, Jochum W, Sulser T and Cremer T (1995) Correlation of microscopic phenotype with genotype in a formalin-fixed, paraffin-embedded testicular germ cell tumor with universal DNA amplification, comparative genomic hybridization, and interphase cytogenetics. Am J Pathol 146: 1332-1340

\section{Uveal melanoma}

Ghazvini S, Char DH, Kroll S, Waldman FM and Pinkel D (1996) Comparative genomic hybridization analysis of archival formalin-fixed paraffin-embedded uveal melanomas. Cancer Genet Cytogenet 90: 95-101

Speicher MR, Prescher G, du Manoir S, Jauch A, Horsthemke B, Bornfeld R, Becher R and Cremer T (1994) Chromosomal gains and losses in uveal melanomas detected by comparative genomic hybridization. Cancer Res $\mathbf{5 4}$ $3817-3838$

\section{Wilms' tumour}

Steenman M, Redeker B, deMeulemeester M, Wiesmeijer K, Voute PA, Westerveld A, Slater R and Mannens M (1997) Comparative genomic hybridization analysis of Wilms' tumors. Cytogenet Cell Genet 77: 296-303

Valentine RAAM, Li H, Boyett JM, Shearer P, Grundy P, Shapiro DN and Look T (1996) Identification of novel regions of deletion in familial Wilms' tumor by comparative genomic hybridization. Cancer Res 56: 3837-3841 